NBER WORKING PAPER SERIES

\title{
REDUCING GREENHOUSE GAS EMISSIONS BY FOREST PROTECTION: THE TRANSACTION COSTS OF REDD
}

\author{
Lee J. Alston \\ Krister Andersson \\ Working Paper 16756 \\ http://www.nber.org/papers/w16756 \\ NATIONAL BUREAU OF ECONOMIC RESEARCH \\ 1050 Massachusetts Avenue \\ Cambridge, MA 02138 \\ February 2011
}

We thank Arun Agrawal, Eric Alston, Richard Jessor, Gary Libecap, Terrence McCabe, Bernardo Mueller, Esther Mwangi, Michael Oppenheimer, Elinor Ostrom, James Poterba, Ashwin Ravikumar, and Barry Weingast,for constructive criticism on earlier drafts. Funding provided by the Institute of Behavioral Science at the University of Colorado, Boulder, and National Science Foundation (HSD0527138; SEB-0648447; and SEB-0528146). The views expressed herein are those of the authors and do not necessarily reflect the views of the National Bureau of Economic Research.

NBER working papers are circulated for discussion and comment purposes. They have not been peerreviewed or been subject to the review by the NBER Board of Directors that accompanies official NBER publications.

(C) 2011 by Lee J. Alston and Krister Andersson. All rights reserved. Short sections of text, not to exceed two paragraphs, may be quoted without explicit permission provided that full credit, including $\odot$ notice, is given to the source. 
Reducing Greenhouse Gas Emissions by Forest Protection: The Transaction Costs of REDD Lee J. Alston and Krister Andersson

NBER Working Paper No. 16756

February 2011

JEL No. H11,H23,K32,K33,K41,K42,O13,O38,O43,Q15,Q2,Q23,Q24,Q34,Q38,Q49,Q54,Q58,R1,R13

\begin{abstract}
$\underline{\text { ABSTRACT }}$
Understanding and minimizing the transaction costs of policy implementation are critical for reducing tropical forest losses. As the international community prepares to launch REDD+, a global initiative to reduce greenhouse gas emissions from tropical deforestation, policymakers need to pay attention to the transactions costs associated with negotiating, monitoring and enforcing contracts between governments and donors. The existing institutional design for REDD+ relies heavily on central government interventions in program countries. Analyzing new data on forest conservation outcomes, we identify several problems with this centralized approach to forest protection. We describe options for a more diversified policy approach that could reduce the full set of transaction costs and thereby improve the efficiency of the market-based approach for conservation.
\end{abstract}

Lee J. Alston

Institutions Program

Institute of Behavioral Science

Department of Economics

University of Colorado at Boulder

Boulder, CO 80309-0483

and NBER

Lee.Alston@colorado.edu

Krister Andersson

Institute of Behavioral Science

Departments of Environmental Studies and Political

Boulder, CO 80309

Krister.Andersson@colorado.edu 


\section{Introduction}

"The reason that some activities are not the subject of contracts is exactly the same reason why some contracts are commonly unsatisfactory - it would cost too much to put the matter right." (Coase, 1960).

Fifty years ago, Ronald Coase articulated the problems with the implementation of government policies to reduce social costs concluding that sometimes the transaction costs to "put the matter right” exceed the benefits. Such transaction costs help explain why past policy efforts have not led to global tropical forest conservation (Andersson and Gibson, 2007; Kaimowitz, 2000). We argue that more attention to transaction costs would benefit the institutional design of a new global program intended to combat tropical deforestation in developing countries, known as REDD+ (hereafter REDD for "Reducing Emissions from Deforestation and Forest Degradation and the Role of Conservation, Sustainable Management of Forests and Enhancement of Forest Carbon Stocks in Developing Countries"). The existing institutional design for REDD is a market-based approach which relies almost exclusively on host-country government monitoring of contractual behaviour which entails a series of incentive incompatibility problems. In addition to the monitoring costs of contractual compliance, negotiating and enforcement costs arise in contracts for forest preservation as they do in all market contracts.

The main objective of REDD is to provide positive economic incentives to people in developing countries to conserve forests and thereby reduce greenhouse gas emissions from one of its leading sources (UNFCCC, 2009; IPCC, 2007). REDD appears to be a win-win solution: developing countries receive payments to preserve their forests and donor countries receive carbon credits and praise for “doing something” about climate change (Aragão et al 2010; Richards and Andersson, 2001). Though REDD seeks to address the core underlying 
problem of tropical forest loss-the social costs of tropical deforestation-the architects of REDD face a range of transaction costs in structuring the program.

\section{How to Reverse Tropical Forest Loss?}

To reverse the current trend of tropical deforestation is a daunting task, partly because we are still in the dark when it comes to making tropical forest conservation work in developing countries. Analysts and practitioners agree that there are no readily available and universal solutions to deforestation and forest degradation (Ostrom et al 2007; Geist and Lambin 2002; Angelsen and Kaimowitz, 1999). Despite international conservation efforts, no country in the modern era has been able to reverse a trend of area decrease in tropical primary forest (FAO, 2010; Puyravaud et al 2010). Examining data from FAO’s Forest Resources Assessment 2010, we analysed changes in the spatial extent of primary forests in all countries with tropical forests during the $1990-2010$ period. We found no country whose forest inventory data showed an increase in primary tropical forest areas. A handful of countries; including China, India, and Vietnam; reported net increases of total forest cover for the 20052010 period, but these figures are driven by the establishment of forest plantations not by decreases in loss of primary tropical forests. In the case of Brazil, deforestation rates have decreased by about 80 per cent since the peak in 2004 (Regalado, 2010). Most scholars agree that this reduction is not primarily attributable to government action but rather to marketrelated factors, such as economic growth in urban areas (causing less migration to the frontier) and sluggish markets for agricultural commodities (Sanchez-Azofeifa and Harriss, 2001; Nepstad et al. 2009).

The challenges faced by national governments when seeking to conserve forests are illustrated by recent empirical work that seeks to tease out the effect of government action on deforestation. Using forest cover data derived from satellite images along with rigorous 
statistical methods, Robalinho et el (2008) and Sanchez-Azofeira et al 2007 investigate the effects of the government of Costa Rica’s payments for environmental services (PES) program. This program is often referred to as a forerunner to REDD programs because it pays land managers to retain tree cover on their land. Robalinho et al (2008) find that the program contributed to merely a one per cent decrease in annual deforestation rates while SanchezAzofeira et al (2007) found no statistically significant effect of the program on forest conservation (looking at a slightly shorter time period). Most of the payments went to land owners with forests that had little or no alternative uses, which means that the owners would have conserved the forest regardless of the program payments.

In addition to PES programs, an even more common strategy for conserving tropical forests is the creation of government protected areas, such as national parks and biosphere reserves. A recent study assesses the effect of Costa Rica’s protected area system on forest conservation. Andam et al (2008) find that about ten per cent of the protected forest areas would have been deforested had they not been part of the government conservation program. A similar study found that the Brazilian government's creation of protected areas in the Amazon reduced deforestation in these areas--a reduction that the authors attribute principally to the government's devolution of property rights for some protected forests to indigenous tribes (Soares-Filho et al., 2010).

Meanwhile in industrialized countries, natural forest cover has increased in some regions over the past thirty years, e.g., in Indiana, along with other states in the Mid-West and Northeast of the United States (Manson and Evans, 2007; Ramankutty et al, 2010). Symmetric to forest loss in tropical regions, the re-growth of natural forests is not primarily attributable to government programs, but to the reduced profitability of small-scale agriculture on marginal soils (Evans and Kelley, 2007). 
These empirical results raise concerns over assigning central governments with the lead responsibility for implementing REDD programs. Even in the cases where government programs demonstrably reduced deforestation, as is the case of protected areas in Costa Rica, it remains an open question whether these interventions were cost-effective or whether the same outcomes may be achievable at lower costs.

The empirical findings also suggest that there are limits to what we can expect national governments to accomplish when it comes to altering established patterns of land use. It appears that land use decisions are primarily a function of markets and local community institutions, and to a lesser extent formal government rules and programs (Ostrom and Nagendra, 2006; Morton et al., 2006; Nepstad et al 2009). To figure out how the forces of the market might be moderated through specific market-based proposals, such as REDD, we need a better understanding of the hidden costs, the transaction costs, associated with such interventions.

\section{The Transaction Costs of REDD}

The core challenge for REDD is to find ways of compensating land owners governments (national and sub-national); indigenous tribes; community groups and individual landowners-for foregoing market opportunities associated with deforestation, and instead, conserve forests (Angelsen, 2010). To address this challenge, markets for tropical forest conservation need to address three substantive transaction costs: the negotiation of contracts with landowners; the monitoring and verification of outcomes; and the enforcement of contracts if the parties do not fulfill their obligations. These transaction costs are present in all contracts but international contracting, especially when third parties are part of the contract, raise a different set of transaction costs than are present in most market contracts.

For international donors to reach an agreement with landowners to switch from deforestation to conservation requires certainty about who owns the land. This may sound 
very simple, but the reality is that in most developing countries there are often multiple owners and users who claim property rights to forest resources (Feder and Feeny 1991; Mwangi and Markelova, 2009). It can be extremely messy to sort out property rights to forests, especially when statutory laws and customary norms assign conflicting rights to users (Larson et al., 2008; White and Martin, 2002). Although, national governments often appear as the formal owner of forest resources-recent research estimates that 75 percent of the world's forest estate is owned by national governments - the de facto forest owners are the local people who actually access, use, and sometimes protect the resource (Sunderlin et al ., 2008). This reality poses a dilemma for REDD policy makers: Who is the contracting party with whom to negotiate for conservation? The governments who in principle own the forest resources or the people who actually use and manage these resources? Limiting conservation inducements to de jure land owners may produce a race among the de facto right holders to "mine the resource” before they are formally excluded from accessing and using the resource (Alden Wily and Dewees, 2001). Such a race would lead to increased deforestation and widened social inequities.

For these reasons, it may be necessary to decouple de jure land ownership from de facto management rights in order to arrive at a market contract that achieves the goal of conservation. Essentially, for markets to work, all the holders of the property rights to the resource need to be part of the contract. ${ }^{1}$ For many countries, this first hurdle will be the most difficult to clear - "it may cost too much to put the matter right."

If, and when, property rights are sorted out and a contract is negotiated for conservation payments, other transaction costs loom ahead: who will monitor and verify the accomplishments? Donors and carbon credit buyers, who are the most ardent advocates of

\footnotetext{
${ }^{1}$ One example of a government initiative that seeks to sort out property rights along these lines is the Terra Legal Program, which was initiated in 2009 in Brazil to grant formal legal title to squatters on public land in the Amazon.
} 
REDD, benefit from cheap credits so they may not want very close inspection (Richards and Andersson, 2001). The sellers of the credits - the developing countries and the carbon market brokers—also have weak incentives to monitor rigorously; they may be on board because of the financial reward, and looking too carefully on reported claims is not really in their interest (Laurance and Venter., 2010). In short, there may be an incentive incompatibility in contracts if the monitors of the outcomes of the contracts do not have an incentive to reliably report performance. Despite technological advances that allows for more reliable monitoring of changes in forest carbon, many uncertainties remain. One of the sources of uncertainty is the program's insistence on additionality—sellers of offset credits need to show that activities rewarded under REDD would not have happened without the program (Karsenty , 2008). Such uncertainties invite strategic participants to tweak the numbers in their favor, which would create offset credits that do not represent real reductions in GHG emissions, but such cheating would be hard to detect even for third-party monitors (Andersson and Richards, 2001; Laurance and Venter, 2010).

Finally, in addition to contracts designed to reduce the negotiation and monitoring costs, enforcement costs remain which are especially problematic in most international transactions because of the inability to rely on a judiciary to arbitrate disputes. How do rich countries credibly commit to withhold payments to poor countries? At the national level, it may be politically costly to enforce commitments when the non-compliers are poor people who may have failed to protect forests for very legitimate reasons: they need to eat (Chomitz et al., 2007). ${ }^{2}$

Many of these transaction costs are hard to quantify, but REDD architects need to take steps to minimize them in order to create a market for conservation. It is only when weighing the true social costs and benefits of relying on forestry for emission reductions that alternative

\footnotetext{
${ }^{2}$ This is analogous to the market failures for home mortgages in many countries. If foreclosures are not politically feasible the capital market for mortgages disappears.
} 
options--such as reducing fossil fuel emissions in industrialized countries or geo-engineering-may be compared.

\section{Reducing the Transaction Costs of REDD}

Solving common-pool resource problems is a difficult challenge even with substantial amounts of external funding (Dietz et al., 2003; Ostrom, 2009; Andersson, E. Ostrom , 2008). Reducing emissions from deforestation will require more than throwing money at the problem. We identify two specific avenues for reducing transaction costs and thus improve contracting for conservation. First, before negotiating any contracts, property rights to forests need to be sorted out, which may well vary considerably across countries and even within countries. The delineation of de facto property rights could be part of field-based forest inventories, which participating REDD countries are likely to be required to conduct in order to qualify for payments (IPCC, 2004). In Tanzania, Ecuador, and Peru, for example, national forest inventories are underway that combine biophysical measurements with field interviews with forest users so that inventory data may be used not only to quantify forest-related carbon pools, but also to identify the de facto holders of property rights (Tomppo and Andersson, 2008). In building a market for forest conservation it makes sense to start with the "low hanging fruit" of deforestation reduction--there are areas where reductions would be the least expensive. Once property rights are known, the holders of property rights will have an incentive to reveal their opportunity costs and buyers can start low and buy conservation preservation up to their budget.

The transaction costs of conservation may be reduced through multi-level governance responses to forest loss. In addition to national governments, other types of organizations, may have lower transaction costs related to the negotiation, monitoring, and enforcement of contracts (Phelps et al 2010; Oestreicher et al., 2009) For example, a local association of 
forest users may do a better job at patrolling, monitoring, and protecting forests over which they have vested user rights, than would central governments (Ostrom and Nagendra, 2006; Dietz et al 2003). An independent research institute may be more neutral, impartial, and has often better technical expertise in monitoring compliance with land use regulations than do government agencies who may have economic and political stakes in the outcome. ${ }^{3}$

An often-overlooked option for multilevel governance is the modification of economic policies in industrialized countries (Long, 2010). Reforming these policies could complement the market for forest conservation. For example, if the United States decided to remove subsidies for ethanol production, this will increase the amount of corn acreage used for nonethanol use as well as increase the acreage planted in soy, which in turn would reduce the incentive for Brazil to expand their soy frontier further into the Southern Amazonian forest.

\section{Concluding Remarks}

All contracts must confront and try to minimize transaction costs. The most common set of transaction costs are negotiation, monitoring and enforcement costs. Relative to two private parties entering into a domestic contract where they contract in the 'shadow' of the domestic legal system, the transaction costs of public contracts increase because of third parties being part of the contract which raises some issues of incentive incompatibility associated with the set of transaction costs that we highlighted. International public or third party contracts do not take place in the 'shadow' of a domestic legal system, such that the participants have an ultimate recourse to the judicial system. At the very least this raises enforcement costs. In the case of contracting to protect forests, uncertainty over property rights and the incentives of the international participants may also increase negotiation and monitoring costs. What this means for REDD is that parties to the program need to be aware

\footnotetext{
${ }^{3}$ An example of a politically impartial monitor of deforestation is Brazil's Instituto Nacional de Pesquisas Espaciais (INPE)
} 
of the set of transaction costs up front--prior to engaging with the program and setting up contracts for buying or selling emission offset credits--so that they can either safeguard themselves from downstream opportunistic behaviour or decide that it is "too costly to put the matter right.” 


\section{References}

Alden Wily, L., \& Dewees, P. A. (2001). From Users to Custodians: Changing Relations between People and the State in Forest Management in Tanzania. World Bank Policy Research Working Paper 2569, 1-31.

Andam, K. S., Ferraro, P. J., Pfaff, A., Sanchez-Azofeifa, G. A., \& Robalino, J. A. (2008). Measuring the effectiveness of protected area networks in reducing deforestation. Proceedings of the National Academy of Sciences, 105(42), 16089-16094.

Andersson, K., \& Gibson, C. C. (2007). Decentralized Governance and Environmental Change: Local Institutional Moderation of Deforestation in Bolivia. Journal of Policy Analysis and Management, 26(1), 99-123.

Andersson, K., \& Ostrom, E. (2008). Analyzing decentralized resource regimes from a polycentric perspective. Policy Sciences, 41(1), 71-93.

Andersson, K., \& Richards, K. (2001). Implementing an international carbon sequestration program: Can the leaky sink be fixed? Climate Policy, 1(2), 173-188.

Angelsen, A. (2010). Policies for reduced deforestation and their impact on agricultural production. Proceedings of the National Academy of Sciences, 107(46), 19639-19644.

Angelsen, A., \& Kaimowitz, D. (1999). Rethinking the Causes of Deforestation: Lessons from Economic Models. The World Bank Research Observer, 14(1), 73-98.

Aragao, L. E. O. C., \& Shimabukuro, Y. E. The Incidence of Fire in Amazonian Forests with Implications for REDD. Science, 328(5983), 1275-1278.

Chomitz, K. M., Buys, P., Luca, G. D., Thomas, T. S., \& Wertz-Kanounnikoff, S. (2007). At Loggerheads? Agricultural Expansion, Poverty Reduction, and Environment in the Tropical Forests. Washington DC: The World Bank.

Dietz, T., Ostrom, E., \& Stern, P. C. (2003). The Struggle to Govern the Commons. Science, 302(5652), 1907-1912. 
Evans, T. P., \& Kelley, H. (2008). Assessing the transition from deforestation to forest regrowth with an agent-based model of land cover change for south-central Indiana (USA). Geoforum, 39(2), 819-832.

Feder, G., \& Feeny, D. (1991). Land Tenure and Property Rights: Theory and Implications for Development Policy. The World Bank Economic Review, 5(1), 135-153.

Geist, H., \& Lambin, E. F. (2002). Proximate Causes and Underlying Driving Forces of Tropical Deforestation Bioscience, 52 143-155.

IPCC. (2007). The Fourth Assessment Report. Bonn, Germany: IPCC.

Kaimowitz, D. (2000). Forestry assistance and tropical deforestation: Why the public doesn't get what it pays for. International Forestry Review, 2(3), 225-231.

Karsenty, A. (2008). The Architecture of Proposed REDD Schemes After Bali: Facing Critical Choices. International Forestry Review, 10(3), 443-457.

Larson, A. M., Cronkleton, P., Barry, D., \& Pacheco, P. (2008). Tenure Rights and Beyond. Bogor, Indonesia: Center for International Forestry Research (CIFOR).

Laurance, W. F., and Venter, O. (2010). Measuring Forest Changes. Science, 328, 568.

Long, A. 2010. Tropical Forest Mitigation Projects and Sustainable Development: Designing U.S. Law for a Supportive Role. William Mitchell Law Review 36 (3): 968-991

Manson, S. M., \& Evans, T. (2007). Agent-based modeling of deforestation in southern Yucat $\tilde{A}_{i n}$, Mexico, and reforestation in the Midwest United States. Proceedings of the National Academy of Sciences, 104(52), 20678-20683.

Morton, D. C., DeFries, R. S., Shimabukuro, Y. E., Anderson, L. O., Arai, E., del Bon Espirito-Santo, F., et al. (2006). Cropland expansion changes deforestation dynamics in the southern Brazilian Amazon. Proceedings of the National Academy of Sciences, 103(39), 14637-14641. 
Mwangi, E., \& Markelova, H. (2009). Collective Action and Property Rights for Poverty Reduction: A Review of Methods and Approaches. Development Policy Review, 27(3), 307-331.

Nepstad, D., Soares-Filho, B. S., Merry, F., Lima, A., Moutinho, P., Carter, J., et al. (2009). The End of Deforestation in the Brazilian Amazon. Science, 326(5958), 1350-1351.

Oestreicher, J. S., Benessaiah, K., Ruiz-Jaen, M. C., Sloan, S., Turner, K., Pelletier, J., et al. (2009). Avoiding deforestation in Panamanian protected areas: An analysis of protection effectiveness and implications for reducing emissions from deforestation and forest degradation. Global Environmental Change, 19(2), 279-291.

Ostrom, E. (2009). A General Framework for Analyzing Sustainability of Social-Ecological Systems. Science, 325(5939), 419-422.

Ostrom, E., \& Nagendra, H. (2006). Insights on linking forests, trees, and people from the air, on the ground, and in the laboratory. Proceedings of the National Academy of Sciences, 103(51), 19224-19231.

Ostrom, E., Janssen, M. A., \& Anderies, J. M. (2007). Going beyond panaceas. Proceedings of the National Academy of Sciences, 104(39), 15176-15178.

Phelps, J., Webb, E. L., \& Agrawal, A. (2010). Does REDD+ Threaten to Recentralize Forest Governance? Science, 328(5976), 312-313.

Puyravaud, J.-P., Davidar, P., \& Laurance, W. F. (2010). Cryptic Loss of India’s Native Forests. Science, 329, 32.

Ramankutty, N., Heller, E., \& Rhemtulla, J. (2010). Prevailing myths about agricultural abandonment and forest regrowth in the United States. Annals of the Association of American Geographers, 100(3), 502-512.

Regalado, A. (2010). Brazil Says Rate of Deforestation in Amazon Continues to Plunge. Science, 329(5997), 1270-1271. 
Richards, K., \& Andersson, K. (2001). The leaky sink: persistent obstacles to a forest carbon sequestration program based on individual projects. Climate Policy, 1(1), 41-54.

Sánchez-Azofeifa, G. A., Harriss, R. C., \& Skole, D. L. (2001). Deforestation in Costa Rica: A Quantitative Analysis Using Remote Sensing Imagery. Biotropica, 33(3), 378-384.

Soares-Filho, B., Moutinho, P., Nepstad, D., Anderson, A., Rodrigues, H., Garcia, R., et al. (2010). Role of Brazilian Amazon protected areas in climate change mitigation. Proceedings of the National Academy of Sciences, 107(24), 10821-10826.

Sunderlin, W. D., Hatcher, J., \& Liddle, M. (2008). From Exclusion to Ownership? Challenges and Opportunities in Advancing Forest Tenure Reform. Washington DC: Rights and Resources Initiative.

UNFCCC. (2009). The Copenhagen Accord (Vol. Decision -/CP15, ): The United Nations Framework Convention for Climate Change

White, A. Martin, A. 2002. Who Owns the World's Forest (Forest Trends, Center for International Environmental Law, Washington, DC). 